This report was prepared as an account of work sponsored by an agency of the United States Government. Neither the United States Government nor any agency thereof, nor any of their employees, makes any warranty, express or implied, or assumes any legal liability or responsibility for the accuracy, completeness, or usefulness of any information, apparatus, product, or process disclosed, or represents that its use would not infringe privately owned rights. Referonce herein to any specific commercial product, process, or service by trade name, trademark, manufacturer, or otherwise does not necessarily constitute or imply its endorsement, recommendation, or favoring by the United States Government or any agency thereof. The views and opinions of euthors expressed herein do not necessarily state or reflect those of the United States Government or any agency thereof.

TRANSFER OF RADIONUCLIDES TO ANIMALS - AN HISTORICAL PERSPECTIVE OF WORK DONE IN THE UNITED STATES

\title{
C. R. RICHMOND
}

Oak Ridge National Laboratory, * Post Office Box 2008, Mail Stop 6253, Oak Ridge, Tennessee 37831-6253 (USA)

\section{INTRODUCTION}

Good afternoon ladies and gentlemen. It is my pleasure to meet with you today at this most historic setting as a participant in this important workshop. I was honored to be asked to contribute both as a speaker and as a member of the program committee.

I would like to start by telling an interesting story about the first recorded tracer study in man (1). It is fitting because the story takes place here in England and the main character is none other than Gcorge Hevesy who was the recipient of a Nobel prize in 1943 for his pioneering work in the application of radionuclides as biological tracers. He was awarded the Atoms for Peace Award in 1959.

"George Hevesy, a young Hungarian physicist working in England, was the first scientist to use an isotopic tracer in biology. In 1923 he immersed the roots of bean plants in solutions containing a radioactive isotope of lcad. He traced the ascent of the lead into the stem and leaves by simply measuring their radioactivity. According to Dr. Hevesy, his first tracer cxperiment was designed for a less exalted purpose. Since he was suffering from the endemic affliction of young scientists of that period, impecuniousness, he was lodging in a yery modest boarding house. He observed that roast beef was invariably followed by hash on the weekly menu. He had strong suspicions that even the meager leavings of the roast beef from the piaies of the boarders greeted them again the following day disguised as hash. Therefore he once sprinkled a trace of radioactivity on his leavings from a meal and the next day he surreptitiously carried off a sample of hash to the laboratory. His instruments confirmed his suspicions: the hash was radioactive." The connection of this story to the workshop topic may not be too far fetched if one thinks of the uptake of the tracer by a live cow rather than by 
Hevesy, a Hungarian who was a truly international scientist, worked in Manchester, England with Rutherford from 1912 to 1920. For the following 6 years he worked with Neils Bohr in Copenhagen. After he received the Nobel prize he was olfered, and accepted, Swedish cilizenship.

\section{MASTER}

*Operated by Martin Marietta Energy Systems, Inc. for the U.S. Department cf Energy under contract DE-AC05-840R21400. 
As part of the preparation for this paper I had a literature search done by the Information Resources Organization at ORNL. The search parameters excluded man and laboratory aninals. Included were the search terms farm animals, radionuclides, metabolism etc. However, many of the retrieved references dealt with investigations of physiological or metabolic parameters using radionuclides that are not of interest to this workshop. Some of these, for example, were related to the use of radionuclides in nuclear medicine. I was also impressed with the large fraction of the usable references that came from laboratories outside of the United States.

Included in the listing are translations of svork done in the Soviet Union. It was also clear that most of the contributions came from only several laboratories and that much of the work was done quite a few years ago. It remains to be seen what the impact of the Chernobyl nuclear power station accident will be on these studies.

One lesson learned from preparing this paper is that the amount of effort devoted to this area of research over the years has been surprisingly small. This is especially true if one compares the total effort with research utilizing radionuclides to study metabolism in laboratory animals.

The search produced several hundred references containing much information on radionuclides and animals. Careful review and verification of the listing need to be completed. This report will not be a comprehensive review of the listing. The purpose of this report is to cover the subject from a historical perspective.

I was also struck by the large number of non-classified internal reports as compared to the number of open literature publications for work done in the U.S. The reason is not clear. Perhaps there were limited numbers of professional journals in which to publish these kinds of data or perhaps the sponsors of the work were more inclined to have the material appear in internal reports rather than open literature publications. Many of the very early studies appeared in the Journal of Dairy Science. For reference, the Radiation Research and Health Physics journals were started in 1954 and 1958, respectively.

In ite mid 1960's, there were five veterinarians assigned to the Division of Biology and Medicine within the U.S. Atomic Energy Commission (AEC) Four were on assignment from the military establishment and one was a civilian. There are none at present and, in fact, there is only one person on staff in the U.S. Department of Energy (progeny organization of the AEC). AEC-supported animal studies in the early 1960's included more than animal metabolism studies e.g., 
agricultural research. Also, in the mid 1960's there was a major change in program emphasis within the AEC. Basic cell biology studies were being developed at the expense of work done in animals. In the latter category, laboratory research had a higher priority than did work with farm animals. Another major change in program emphasis is happening now with the increasing emphasis on work on the Human Genome Program.

\section{WHY IS THIS WORKSHOP OF INTEREST?}

Nuclear fuel cycle

Concem for radioactive releases from the nuclear fuel cycle has provided the incentive for many studies of interest to this workshop. There were early concems about the uptake of radionuclides by human beings eating fish caught in the Columbia river near the Hanford site. In some cases the information on the uptake of materials such as $65 \mathrm{Zn}$ by fish and then man could be verified by whole body counting techniques. Large reactor operations and fuel reprocessing operations took place at the Hanford site.

Studies were also undertaken at other DOE facilities such as Savannah River, Rocky Flats, Idaho Falls, and Oak Ridge.

The development of commercial nuclear power also required data and models that predicted uptake of radionuclides by people living in the vicinity of the facility. The interests were mainly in fission products and, to a lesser extent, neutron activation products. These models will not be discussed in this presentation.

In more recent years the emphasis has shifted to the possibility of contamination of the general public from radioactive sources associated with disposal of nuclear or mixed (chemical and nuclear) wastes.

\section{Chernobyl}

The accident at the nuclear power station at Chernobyl in the Soviet Union created a large and almost instant demand for information. Governments around the world were extremely concemed for the health and safety of its citizens both from direct effects of atmospheric fallout and from the ingestion of plant and animal products containing radioactive materials.

There was also an economic faciur in these considerations and, in retrospect, some decisions were made under the pressures of the time that are now viewed as being unsound. There was an urgent need for information of the kind being discussed at this workshop. In some cases, generic information was used to advantage; in others, lessons were leamed too late to be of help or by trial and error. For 
example, it came as a surprise to many that the levels of cesium in the milk of goats and sheep were higher than those of cows from the same general location. Also a surprise to some was the high level of contamination in reindeer. These situations were predictable because of information collected decades ago from animal studies designed to understand the uptake, distribution, retention and loss of radionuclides originating in nuclear-weapons fallout (2). Neither should it have been surprising to find high levels of contamination in mushrooms or in animals, including man, that eat them (3).

A recent report from the Oak Ridge National Laboratory (4) indicates the large uncertainties that exist when one attempts to estimate the amount of radiocesium from Chemobyl that would find its way to man. Many parameters are required for the many models used to move the material from source, through the environment, including animals that are eaten as food, to man. The data indicate that the amount actually detected in people was between one and two orders of magnitude lower than that predicted by the models. Much is known about cesium because of its presence in nuclear fallout and its ease of measurement in man. One can only wonder how good the data are for other radionuclides.

\section{SPACE APPLICATIONS OF RADIOISOTOPES}

\section{Radioisotope Thermoelectric Generators (RTG)}

Both the U.S. and the Soviet Union use radioisotope thermoelectric generators (RTG) as power sources for space systems. The fuel currently used by the U.S. is mainly $238 \mathrm{Pu}$ with about $20 \% 239 \mathrm{Pu}$ by activity. Shortly after launch in April 1964, a U.S. satellite, SNAP 9A, re-entered the atmosphere and burned up at high altitude over the riozambique channel. The radioactive inventory, $6.3 * 10^{14} \mathrm{~B} \mathrm{q}$ (17 kCi) of $238 \mathrm{Pu}$, reentered primarily through the southern hemisphere. Subsequently, $238 \mathrm{Pu}$ was measured for many years in air samples and on the ground. This large input of $238 \mathrm{Pu}$ greatly perturbed the global $238 \mathrm{Pu} / 239 \mathrm{Pu}$ ratios resulting from nuclear weapons testing. In addition, $4.8 * 10^{11} \mathrm{~Bq}(13 \mathrm{Ci})$ of ${ }^{239} \mathrm{Pu}$ from SNAP $9 \mathrm{~A}$ were part of the source term.

Other accidents have occurred with no significant releases of radioactivity. However, one U.S. manned mission to the moon, Apollo 13, experienced a failure mode that resuited in the RTG being retumed to Earth. The $1.7 * 10^{15} \mathrm{~Bq}$ (44.5 kCi) $238 \mathrm{Pu}$ inventory attached to the lunar landing vehicle ended up near the Tonga Trench, as planned, in the Pacific Ocean. The power source also contained $1.2 * 10^{12} \mathrm{~Bq}(33 \mathrm{Ci}){ }^{239} \mathrm{Pu}(5)$.

There were plans to launch several large RTG's in 1986. just after the U.S. space shuttle Challenger accident. These missions, Ulysses and Galilio, were scheduled 
to use three RTGs containing almost $1.5 * 10^{16} \mathrm{~Bq}(400 \mathrm{kCi}) 238 \mathrm{Pu}$; two RTG's containing a total of $1 * 10^{16} \mathrm{~Bq}(265 \mathrm{kCi})$ aboard Galileo and a single RTG on Ulysses. These missions are being critically re-evaluated at present.

\section{Cosmos nuclear pewer reactors}

A 14 May, 1988 article in the Knoxville News-Sentinel (Tennessee) reported that the satellite Kosmos 1900 had been in a steadily decaying orbit for a month and, if no orbital corrections were made, the satellite would enter Earth's atmosphere (6). Kosmos 1900's orbit covers the Earth between 65 degrees south and north latitude excluding Antarctica in the south and a swath in the north bounded by the inhabited areas of Alaska, Greenland. Siberia and Scandinavia. The concern expressed in the article was that the reentering satellite would "shower the Earth with radioactive debris". Kosmos 1900 is a RORSAT, an English-language designation which stands for Radar Ocean Reconnaissance Satellite. The Soviet Union launched Kosmos 1900 on 12 December, 1987 and lost radio contact with the craft in April. They expect the satellite to reenter in August or September. An 8 August 1988 article in the Knoxville News-Sentinel points out that the U.S. Federal officials have begun contingency planning in case Kosmos 1900 reenters and impacts on U.S. territory (7). The Federal Emergency Management Agency is coordinating the planning.

Two other satellites in the Kosmos RORSAT series have fallen from orbit. Kosmos 954 , powered by $50 \mathrm{~kg}$ ( 110 pounds) of Uranium, reentered the atmosphere in January 1978 and spread radioactive contamination across parts of Canada. On 23 January, 1983. Kosmos 1402 dropped from orbit over the Indian Ocean. The NewsSentinel article states that no radioactive debris is known to have fallen to Earth. Of interest is a report that appeared in Health Physics in 1984 (8) concerning the detection of uranium isotopes in the U.S. confirming the destruction of Kosmos 1402. Apparently the article meant earth in the sense of land rather than the planet Earth.

Current predictions are that the amount of radioactive materials used in space applications will continue to increase. A recent article in Time magazine points out that 7 countries (9) now have the capability to launch satellites. According to the article, Israel will soon become the eighth. ${ }^{*}$ Most if not all these countries have the capability to use radionuclides as power sources in these satellites.

* Isreal successfully launched the satellite shortly after the workshop. 


\section{EARLY WORK IN THE U.S.}

\section{Hanford. Washington}

It is clear that much of the early work in the U.S. of interest to this workshop was done at the Hanford site in the state of Washington. A leader in this effort was Dr. Leo K. Bustad, a veterinarian, who had the foresight to recognize the importance and need for these kind of studies. Bustad also was a prime advocate for the use of the "mini pig" in animal studies using radionuclides (10). This allowed the researcher to use an animal larger than the dog or non-human primate in mass and one that had many characteristics, including body mass, in common with human subjects.

There is an old German saying that goes as follows:

dogs look up to man;

cats look down on him;

the pig looks him right in the eye.

The earliest research interests at Hanford involved radioisotopes of iodine. These materials, notably $131 \mathrm{I}$, were released from the facility at Hanford and were of interest because of its presence in nuclear weapons fallout. An example of early work published by this group was on the chronic administration of 131 I to sheep that appeared in 1957 (11). Another example is the 1963 paper on the thyroid uptake of $131_{1}$ by sheep following various routes of administration (12). In 1965, Shannon et al., reported on the public health aspects of Cs-137 in ruminants (13). Weeks et al., reported on the uptake of plutonium by pigs in 1956 (14).

There was also a major interest at Hanford in the early years in using a miniature goat for metabolic studies (15). Dr. Bustad was also heavily involved in these efforts. Another key contributor to work at Hanford was Dr. R. O. McClellan, also a veterinarian, became the director of the Inhalation Toxicology Research Institute in Albuquerque, New Mexico.

Strontium-90 was also studied in a variety of animals because it is a high-yield product of nuclear fission (16). It is also clear that some of the long term studies at Hanford were never completed because of guidance from the sponsoring agency. An example is the complete data analysis of the ${ }^{90} \mathrm{Sr}$ swine studies.

University of Tennessee - Atomic Energy Commission/Agricultural Research Laboratory (UT-AEC/ARL). Oak Ridge. TN

In 1948 the U.S. Atomic Energy Commission (AEC) and the University of Tennessee (UT) established at Oak Ridge, TN, a cooperative research program to study the effects of radiation from nuclear weapons fallout on a herd of Hereford cattle 
accidentally contaminated during the testing of the first atomic bomb detonation at Alamogordo, New Mexico in 1945. This cooperative program led to the establishment of the UT-AEC Agricultural Research Laboratory. The research program was rapidly expanded to include radioisotope studies and radiation effects of agricultural products. From its inception the laboratory has contributed to the understanding of the transport of radionuclides into mans food chain and to the biological effects of external radiation on plants and animals.

As an example, the following list illustrates the diverse research endeavors undertaken at that site:

- studies on the effects of irradiation of the central nervous system

- reproduction

- unilateral vs bilateral irradiation of swine

- late effects of burros surviving mixed radiations from atomic bombs

- radionuclide metabolism in beef cattle, sheep, swine and poultry

- embryo morphology and radiosensitivity

- mutations from irradiated seeds

Among the radionuclides studied were ${ }^{32} \mathrm{P},{ }^{45} \mathrm{Ca},{ }^{65} \mathrm{Zn},{ }^{75} \mathrm{Se},{ }^{89} \mathrm{Sr},{ }^{90} \mathrm{Sr},{ }^{13} 1_{\mathrm{I}},{ }^{134} \mathrm{Cs}$, ${ }^{137} \mathrm{Cs}$, and ${ }^{144} \mathrm{Ce}-{ }^{144} \mathrm{Pr}$.

An example of an early publication from the Oak Ridge group is the 1953 publication by Hood and Comar on the metabolism of $137 \mathrm{Cs}$ by mice and farm animals (17). Another, on $18 \mathrm{~F}$ in domestic animals, was reported in 1955 (18). Mraz and coworkers published information on $C s$ and $K$ metabolism in sheen (19) and swine (20). Data on the uptake and excretion of $\mathrm{Cs}$ and $\mathrm{K}$ in lactating dairy cows was reported by Cragle in 1961 (21).

In 1973 the laboratory became known as the Comparative Animal Research Laboratory (CARL) and its primary concern was a program designed to estimate the risk to man from effluents of energy producing systems. Extrapolation of data from animal systems to man was of prime interest to researchers at CARL.

Niobium-95 metabolism in newborn and weanling swine and sheep was of interest to the Oak Ridge group. Some of these siudies were reported by Mraz and Eisele in 1977 (22).

In more recent years some work was done with transuranic radionuclides, notably americium (23). The facilities are currently part of the Oak Ridge 
Associated Universities (ORAU). The ORAU mission no longer includes research using animals and radionuclides.

\section{Comell University. Ithaca. New York}

Onc of the key investigators at the Oak Ridge facility was Dr. Cyril Comar who contributed much to our understanding of the metabolism of radionuclides in animals. Comar left Oak Ridge to work at the New York State Veterinary College (Department of Physical Biology) at Cornell University where he and his colleagues continued work on the same subject. However, the Comell program was expanded considerably beyond "animal metabolism" investigations.

The Cornell group under Comar remained active for many years. Wasserman et al., reported on the metabolic behaviour of $\mathrm{Cs}-137$ and $\mathrm{Ba}-137 \mathrm{~m}$ in lactating goats (24). Another key individual in this activity was Dr. Fred Lengemann who recently retired from Comell. In 1968 he and his coworkers reported on predictions of Cs-137 intake from milk by human populations following a short term deposition event (25)

\section{Colorade State University (CSU). Fon Collins, Colorado}

Some important studies have been done in the Department of Animal Sciences at Colorado State University by Dr. G. Ward and colleagues. A report on the effects of feeding practices on Cs-137 levels in milk appeared in 1965 (26). In 1969, the CSU group reported on the transfer of fallout Cs-137 from feed to meat of cattle (27). This group is somewhat unique in that they are still very active as witnessed by their participation in this meeting and recent publications $(28,29)$.

\section{INTERSPECIES CORRELATIONS}

We can learn much from interspecies correlations. I think a great deal. For example, Figure 1 shows the relation between heat production and body weight for animals ranging in mass from the mouse to the elephant. Although heat production based on body surface predicts a function with a slope of $2 / 3$, the actual slope is $3 / 4(30)$. Figure 2 gives the relation between the log of water loss and the $\log$ of body weight for animals ranging in size from the mouse to the horse. The regression coefficient, $(0.8006 \pm 0.0692)$ indicates that daily body water tumover is not proportional to body weight; if it were the value would be unity (31). Note that the desert kangaroo rat (Dipodomys) does not fit the reiation as it has developed special mechanisms for living in a very xeric environment. Figure 3 relates $\log$ body water and $\log$ body solids for the 7 species. This relation shows that the ratio of wster to solids is relatively constant for the 7 species and indicates that the degree of tissue hydration is quite normal in the Kangaroo rat. This emphasizes the fact that the unusual ability of this species to 
exist in the desert involves special adaptations of the kidneys for conservation of water and not specialized water depots (31).

I thought I would share an interesting observation about how some bench scientists have been confused by observed differences in the metabolism of materials by animals. Cesium has been widely studied and much is known about the metabolism of this radionuclide in a large variety of animals and in man. However, when interspecies relations were being developed for cesium it became clear that although the data for many species conformed to allometric relations based on metabolic rate or body weight, the values for some animals clearly deviated from "expected" values. One such example is given in Figure 4 which shows the log-log relation of biological half-time (for the longest retention component) to body weight for 12 species of animals given radiocesium (32). The data analysis showed that two separate power functions could describe the data. It became clear that the monogastric mammals constituted one group and the ruminants (multi-chambered mammals) constituted still another group. Both sets of data can be fitted by power functions. The ruminants, often consumed by man as food, will reach equilibrium with environmental cesium at lower levels than those levels predicted from the body weight relation for mono-gastric mammals. Incidentally, it is not clear why the authors included the hen in these data as they refer to "mammalian species."

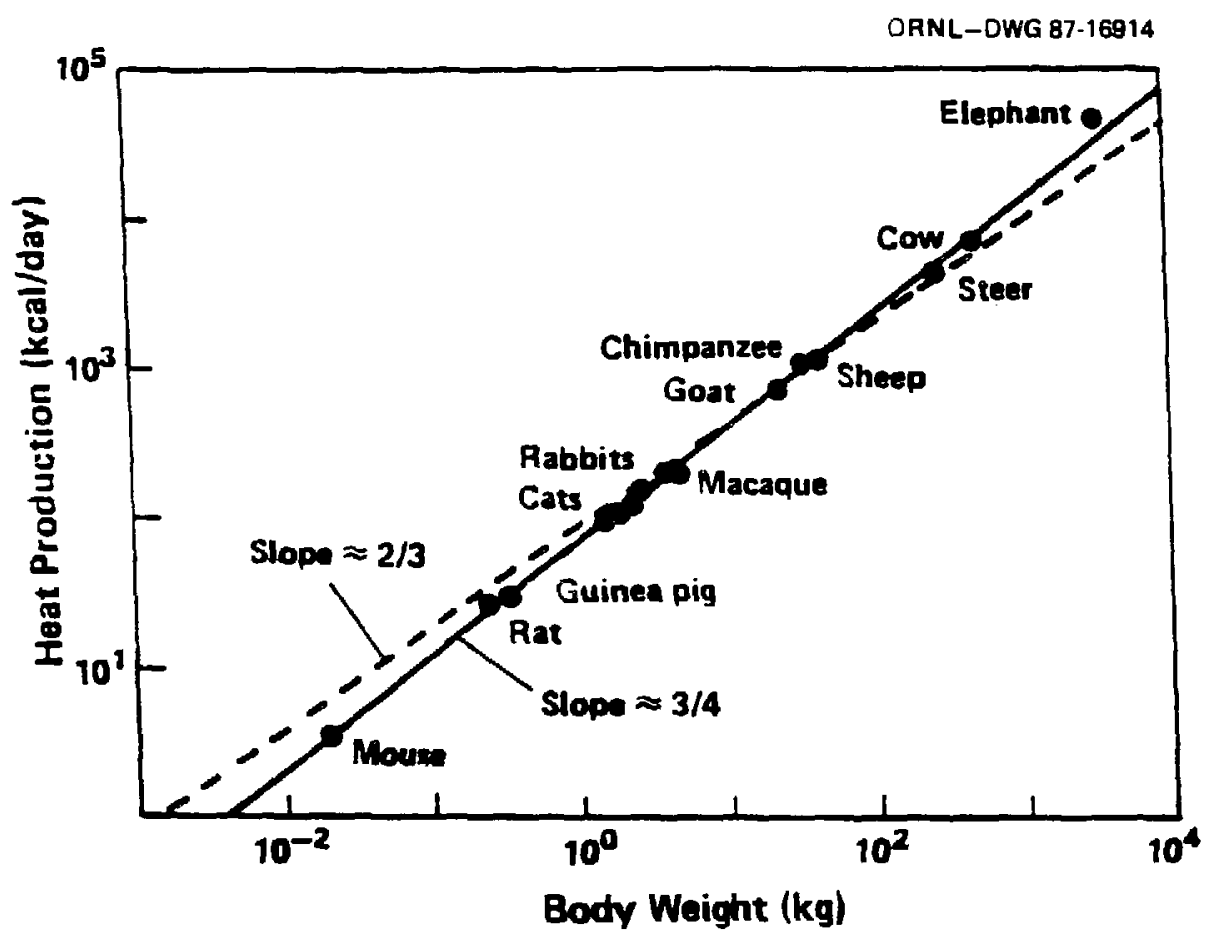

Figure 1. Interspecies correlation between log of heat production and $\log$ of body weight for 12 species. 


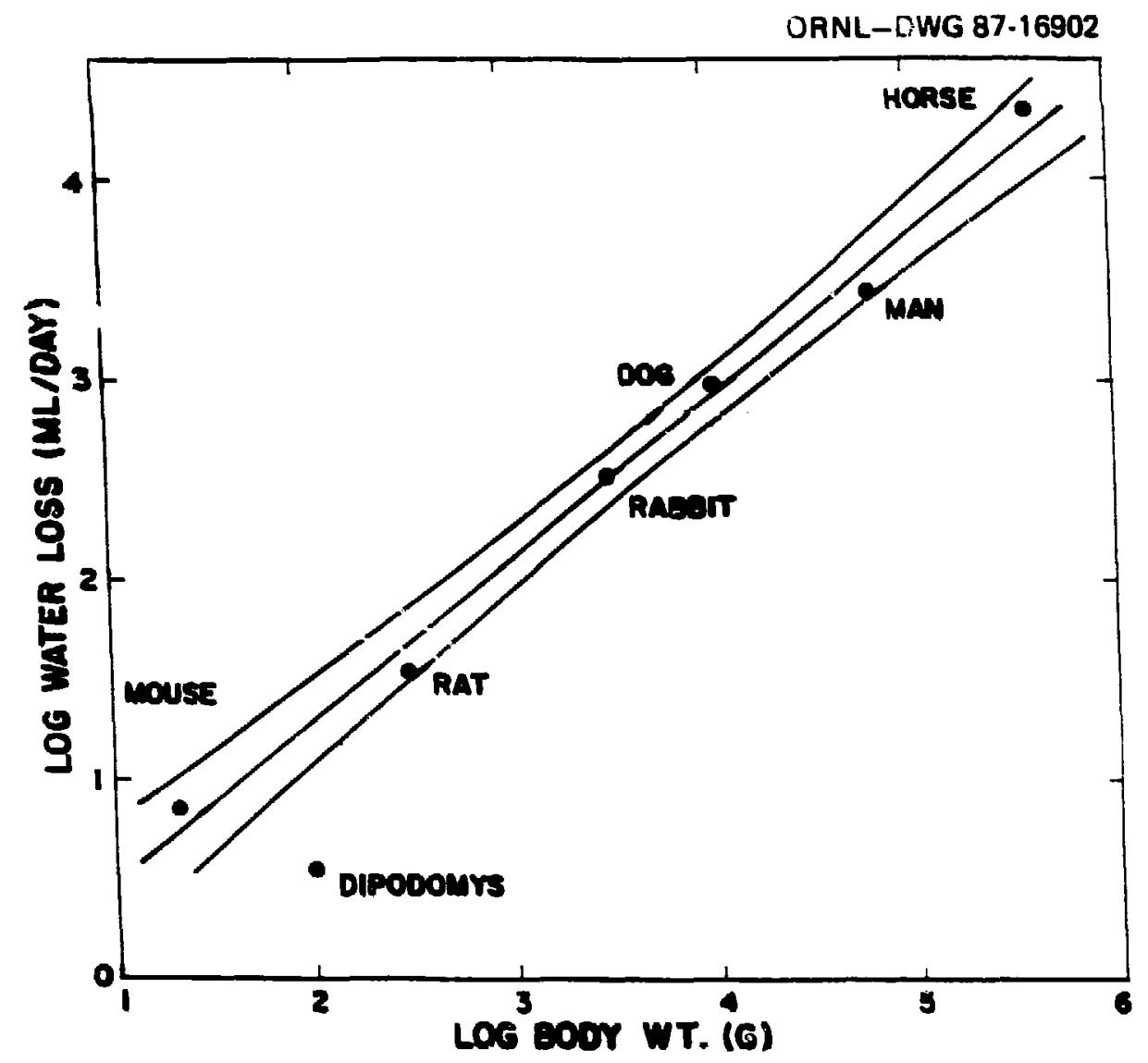

Figure 2. Interspecific correlation between log daily water loss and log body weight for 7 species.

ORNL-DWG 87-16903

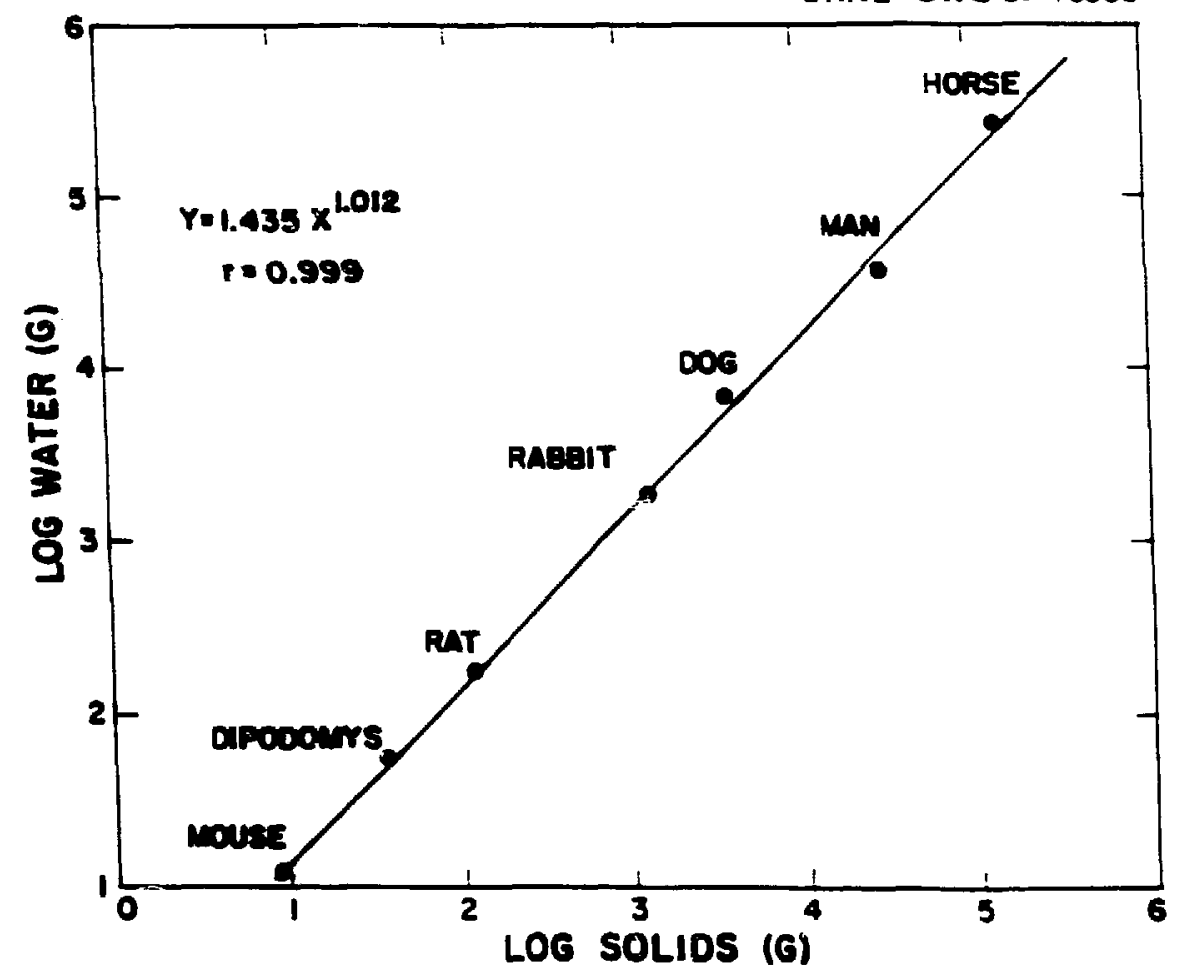

Figure 3. Interspecific correlation between log body water content and log body solids content for 7 species. 


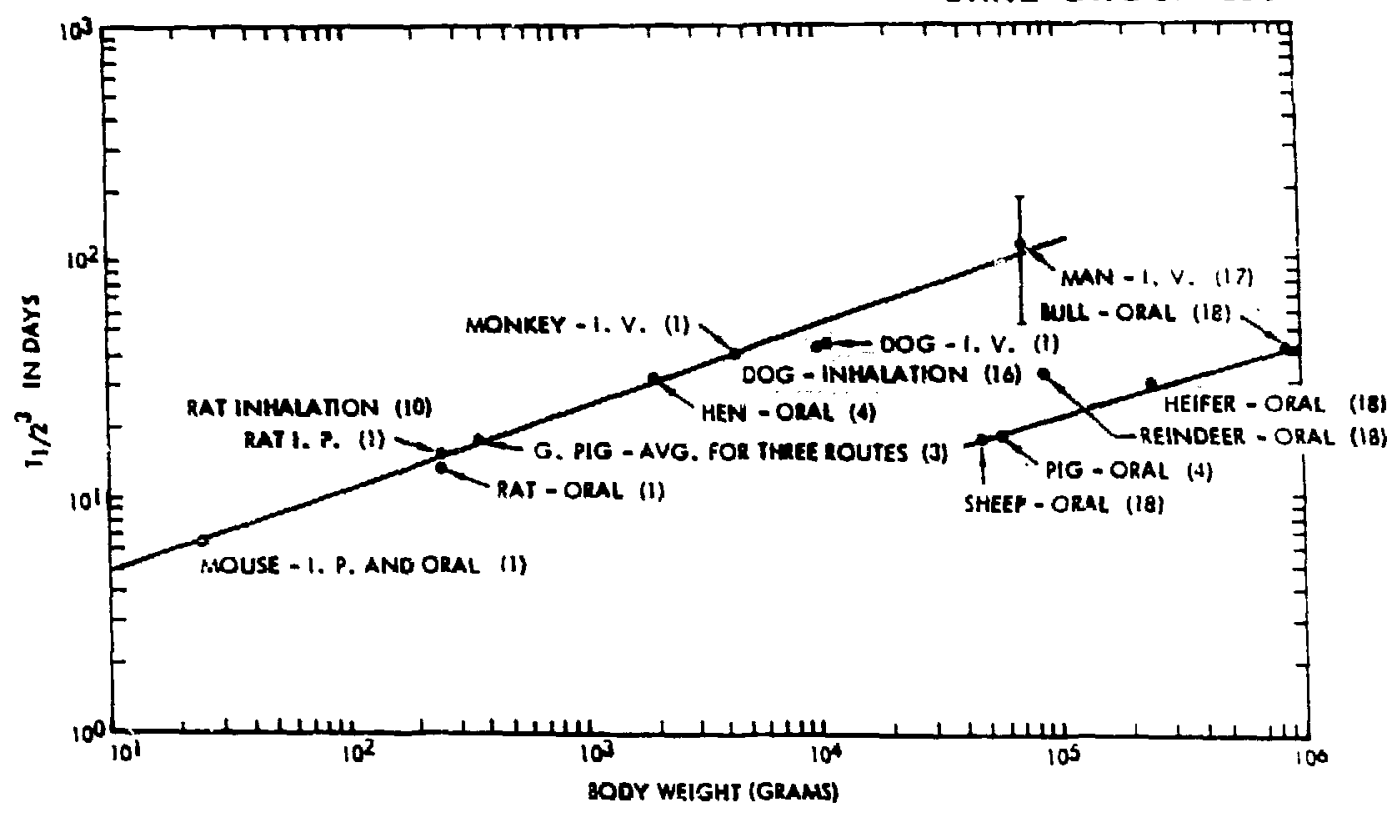

Figure 4. Interspecies correlation between $\log$ biological halflife of cesium and $\log$ body weight.

\section{ACCIERATING TURNUVER OF INCORPORATED RADIONUCLIDES}

A word needs to be said about accelerating the tumover of radionuclides from animals following incorporation from the environment. Considerable work has been done in laboratory animals and some work has been done in human subjects; there is in existence literature concerning this subject (33). Data also exist on the effects of dietary compositions on the transfer coefficients (percent intake per liter of milk) for radionuclides in farm animals (34).

\section{Ferric ferrocyanide. (FFC)}

Prussian bluc, ferric ferrocyanide, has proved very effective in accelerating the loss of radionuclides of cesium following incorporation in the body. This material is available for use by human subjects in some countries and is kept available in nuclear power stations for use following internal contamination. FFC is also effective in reducing the body content of rubidium, another group I element.

FFC was used to reduce the body burdens of animals after the Chernobyl accident. Some work was aiso undertaken to study the effect of FFC on altering the human body content of radiocesium originating from Chemobyl (35). Some of the people exposed to ${ }^{137} \mathrm{Cs}$ in Goiania, Brazil, were treated with FFC (36). 
Various materials have been used to decrease the uptake of radionuclides by animals and others have been lised to acclerate the turnover of the radionuclide after incorporation into the body. Some of these materials, shown in Table 1, were summarized for radiocesium almost twenty years ago (37).

\section{SUMMARY}

This report presents a historical perspective of work done in the U.S. on the metabolism of radionuclides by animals. Also covered are the important concepts of interspecies metabolic correlations and means of accelerating turnover of intemally deposited radionuclides. Although a large amount of data exist for a large number of radionuclides and animal species there are many parameters of interest and additional data is needed. Also, much of the data are in internal reports that are not easily accessible. In-depth reviews of work done in the U.S. are not available.

If I were asked for recommendations following this workshop, I would propose the formation of a committee to comprehensively review the available data on the metabolism of radionuclides by animals and, if necessary, to plan work that could be conducted by multinational teams of scientists. The results of the planned experiments would remove the remaining uncertainties associated with the uptake, retention and loss of radionuclides by animals that are of economic importance, primarily as food sources, to man. The data would also provide the necessary input to other international efforts related to the calculation of radiation dose per unit intake for members of the general public. These kinds of joint international studies are common in the physical sciences. More are needed in the biological sciences. In addition, this is truly a global problem requiring international collaboration and cocperation. The sharing of the burden would help ensure the collection of the necessary data in a timely and cost effective manner. 
TABLE 1. Materials tested as possible antidotes for internal radioactive cesium contamination in animals and man

\section{Materials}

Desoxycorticosterone

Parathyroid extract, cortisone and dinestrol diacetate

Dietary $\mathrm{Na}$ and $\mathrm{K}$

Oat hulls, alfalfa, soybean oil meal

Bentonite, vermiculite, amberlite, alfalfa and beet pulp

Dietary Cs

Desiccated thyroid, $\mathrm{Na}$ and $\mathrm{K}$

Citric acid, oxalic acid, $\mathrm{Na}$ citrate and $\mathrm{Ca}$ gluconate

Levulinic acid oxime and $\alpha$-ketoglutaric acid oxime

Diamox

Acetazolamide

Dietary $\mathrm{K}$

\section{EDTA}

Diuretics

Temperature

Ferric cyanoferrate (II)

Chlorothiazide

Prussian blue

Ferric ferrocyanide

Chlorothiazide, acetozolamide and chloride

\section{References}

Dorfman and Potts, 1947

Mraz, LeNoir, Pinajian and

Patrick, 1956

Mraz, LeNoir, Pinajian and

Patrick, 1957

Wasserman, Comar and Tapper, 1963

Mraz and Patrick, 1957a

Mraz and Patrick, $1957 b$

Ogawa, Machida, Suzuki and Shibate, 1958

Furchner and Richmond, 1962

Mraz and Johnson, 1958

Ryabova, 1958

Takamiya, 1960

Richmond and Furchner, $1961 a$

Sastry and Bush, 1962

Richmond and Furchner, $1961 b$

Wasserman and Comar, 1961

McNeill, Green and Rapoport, 1961

Geller, 1963

Rosoff, Cohn and Spencer, 1963

Furchner and Richmond, 1963

Furchner, Richmond and Drake, 1965

Nigrovic, 1963

Harris and McNeill, 1964

Nigrovic, 1965

Nigrovic, Bohne and Madshus, 1966

Madshus, Stromme. Bohne and

Nigrovic, 1966

Richmond and Bunde, 1966

Sastry and Bush, 1964

References in Table 1 appear in full in the original publication.

\section{REFERENCES}

1. Emest Borek, The Atoms Within Us, Columbia University Press, pp. xii \& 272. 1961.

2. Y. C. Ng and F. O. Hoffman, "Selection of Terrestrial Transfer Factors For Radiological Assessment Models and Regulatory Guides," In: Proceedings of a Seminar on The Environmantal Transfer to Man of Radionuclides Released from Nuclear Installations, Commission of the European Communities, V/7400/84-EN, FR, Volume II, pps. 841-855, Luxembourg, 1984.

3. H. Grueter, "Radioactive Fission Product Cesium-137 in Mushrooms in W. Germany during 1963-1970," Health Phys. 20(6): 655-656, 1971. See also Wallace Johnson and Chester L. Nayfield, "Elevated Levels of Cesium-137 in 
4. C. R. Richmond et al., The Potential Use of Chemobyl Fallout Data to Test and Evaluate the Predictions of Environmental Radiological Assessment Models, ORNL/TM-6466, June 1988.

5. Thaddeus J. Dobry, Jr., "Transuranic Elements in Space Nuclear Power Systems," Transuranic Elements in the Environment, DOE/TIC-2280, Technical Information Center, U.S. Department of Energy, pps. 83-85, 1980.

6. Knoxville News Sentinel, Knoxville, Tennessee, May 14, 1988.

7. The Oak Ridger, Oak Ridge, Tennessee, August 8, 1988.

8. B. L. Tracy et al., "Health Impact of Radioactive Debris from the Satellite Cosmos 954," Health Phys. 47(2): 225-233, 1984.

9. Tirie Magazine, p. 38, August 29, 1988.

10. L. K. Bustad and R. O. McClellan, "Use of Pigs in Biomedical Research," Nature 208(5010): $531-535,1965$.

11. L. K. Bustad et al., "Biological Effects of I-131 Continuously Administered to Sheep," Radiat. Res. 6: 380-413, 1957.

12. D. H. Wood et al., "Thyroid Uptake of Radioiodine Following Various Routes of Administration," Health Phys. 9: 1217-1220, 1963.

13. R. O. Shannon et al., "Public Health Aspects of Cs-137 in Ruminants," J. Am. Vet. Assoc. 147: 1488-1491, 1965.

14. M. H. Weeks et al., "Further Studies on the Gastrointestinal Absorption of Plutonium," Radiat. Res. 4: 339-347, 1956.

15. H. A. Ragan et al., "Application of Miniature Goats in Ruminant Research," Am. I. Vet. Res. 27(116): 161-165, 1966.

16. R. O. McClellan et al., "Preliminary Observations on the Biological Effects of ${ }^{90} \mathrm{Sr}$ in Miniature Swine," Am. J. Vet. Res., 23: 910-912, 1962.

17. S. L. Hood and C. L. Comar, "Metabolism of Cs-137 in Rats and Farm Animals," Arch. Biochem. Biophys. 45: 423-433, 1953.

18. J. D. Perkinson. Jr. et al." "Metabolism of Flourine 18 in Domestic Animals," Am. J. Physiol. 182: 383-389, 1955.

19. F. R. Mraz, "Influence of dietary potassium and sodium on Cs-134 and K-42 excretion in sheep," J. Nutrition 68: 655-662, 1959.

20. F. R. Mraz, A. M. Johnson and H. Patrick, "Metabolism of $\mathrm{Cs}$ and $\mathrm{K}$ in swine as indicated by Cs-134 and K-42," J. Nutrition 64: 541-548, 1958.

21. R. G. Cragle, "Uptake and excretions of Cs-134 and potassium in lactating dairy cows," J. Dairy Science 44: 253-257, 1961.

22. F. R. Mraz and G. R. Eisele. "Gastrointestinal Absorption, Tissue Distribution, and Excretion of $95 \mathrm{Nb}$ in Newíūan and Weanling Swine and Sheep," Radiat. Res. 72(3): 533-536, 1977.

23. G. R. Eisele at al., "Gastrointestinal Absorption of Am"241 by Orally Exposed Swine: Comparison of Experimental Results with Predictions of Metabolic Models," Radiat. Res. 112: pp. 62-73, 1987. See also G. R. Eisele et al., Americium Absorption from the Gastrointestinal Tract of the Pig," Progress Report, October 1, 1979 - September 30, 1982, 76 NVO-252 NTS8306. Dec. 1982.

24. R. H. Wasserman, C. L. Cowan, A. R. Twardock, "Metabolic behavior of Cs-137, Ba-137 in the lactating goat," Int. J. Rad. Biol. 4: 299-310, 1962.

25. F. W. Lengemann, R. A. Wentworth and R. L. Hiltz, "Predicting the Cs-137 intake from milk of a human population after a single, short-term deposition of the radionuclide," Health Physics 14: 101-109, 1968.

26. G. M. Ward, H. F. Stewart and J. E. Johnson, "Effects of feeding practices on Cs137 levels in milk," J. Dairy Sci. 48: 38-43. 1965.

27. J. E. Johnson et al., "Transfer of Fallout Cs-137 from Feed to Meat of Cattie," $J$. Anim. Sci. 29: 695-699, 1969.

28. J. E. Johnson et al., "Transfer Coefficients of Selected Radionuclides to Animal Products. I. Comparison of Milk and Meat from Dairy Cows and Goats," Health Phys. 54(2): 161-166, 1988.

29. J. E. Ennis, Jr. et al., "Transfer Coefficients of Selected Radionuclides to Animal Products. II, Hen Eggs and Meat." Health Phys. 54(2): 167-170, 1988.

30. G. B. West, "Scale and Dimension," Los Alamos Science, pps 2-11, Summer/Fall, 1984.

31. C. R. Richmond et al., "Comparative Metabolism of Tritiated Water by Mammals," J. of Cellular and Comparative Physiology 59(1): 45-53, 1962. 
32. J. F. Stara et al., Comparative Metabolism of Radionuclides in Mammals: A Review, Health Phys. 20: 113-137, 1971.

33. C. R. Richmond and D. E. Bunde, "Enhancement of Cesium-137 Excretion by Rats Maintained Chronically on Ferric Ferrocyanide," Proc. Soc. Exptl. Biol. Med. 121: 774-670, 1966.

34. James E. Johnson et al., "Metabolism of Radioactive Cesium ( ${ }^{134} \mathrm{Cs}$ and ${ }^{137} \mathrm{Cs}$ ) and Potassium by Dairy Cattle as Influenced by High and Low Forage Diets," $J$. Nutr. 94(3): 282-288, 1968.

35. V. Volf et al., "The Effect of Prussian Blue on Cesium in Man after the Tchemobyl Reactor Accident," p. 57 in Procetdings of the 8th International Congress of Radiation Research. Vol. 1, ed. E. M. Fielden, et al., Taylor and Francis, Inc., London, , 1987.

36. L. Bertelli and J. L. Lipstein, "Age-Dependent Cs-137 Biological Half-Lifes Under the Effect of Administration of 'Prussian Blue' in the Goiania Accident," Health Phys. 54(1): S63, 1988.

37. Richmond, C. R., "Accelerating the Turnover of Internally Deposited Radiocesium, Diagnosis and Treatment of Deposited Radionuclides," Proceedings of a Symposium, Richland, Washington, May 15-17, 1967, Excerpta Medica Foundation, pps. 315-328, 1969. 